\title{
Diazotrophic bacteria and nitrogen fertilization on the growth of micropropagated pineapple plantlets during acclimatization
}

\author{
Bactérias diazotróficas e adubação nitrogenada no crescimento de mudas micropropagadas de \\ abacaxizeiro durante a aclimatização
}

\author{
Aurilena de Aviz Silva ${ }^{I^{*}}$ Almy Junior Cordeiro de Carvalho ${ }^{I}$ Flávia Paiva de Freitas $^{\mathrm{I}}$ \\ Patrícia Gomes de Oliveira Pessanha ${ }^{I}$ Paulo Cesar dos Santos ${ }^{I}$ Mírian Peixoto Soares da Silva ${ }^{\mathrm{I}}$ \\ Tábatha de Souza Vasconcelos ${ }^{\mathrm{I}}$ Fábio Lopes Olivares ${ }^{\mathrm{I}}$
}

\begin{abstract}
This study examines the effect of inoculation with diazotrophic bacteria and nitrogen fertilization on the growth of micropropagated pineapple $\mathrm{cv}$. 'Vitoria' plantlets during the acclimatization period. The experiment was carried out in a greenhouse in Campos dos Goytacazes, in randomized blocks, using a 2x5x5 factorial scheme, with the factors being two types of inocula (absence or presence of a mixture of diazotrophic bacteria that contained Burkholderia sp. UENF 114111, Burkholderia silvatlantica UENF 11711, and Herbaspirillum seropedicae HRC 54), five levels of urea $\left(0,2,5,7\right.$, and $\left.10 \mathrm{~g} \mathrm{~L}^{-1}\right)$, and five evaluation periods (30, 60, 90, 120 , and 150 days following the planting of plantlets in trays), and with four replications of each treatment. An increase in the dried weight of shoots and roots of micropropagated pineapple cv. 'Vitória' plants depended on inoculation with diazotrophic bacteria, and plantlets acclimatization could be reduced by up to 57 days, depending on the concentration of urea fertilizer.
\end{abstract}

Key words: Ananas comosus, plant growth-promoting bacteria, nitrogen.

RESUMO

$O$ objetivo deste trabalho foi estudar o efeito da inoculação de bactérias diazotróficas endofiticas e adubação nitrogenada no crescimento de mudas micropropagadas de abacaxizeiro 'Vitória' durante o periodo de aclimatização. $O$ delineamento experimental foi de blocos casualizados (DBC), em esquema fatorial (2x5x5), sendo os fatores representados por dois tipos de inóculos (ausência e presença de uma mistura de bactérias diazotróficas contendo Burkholderia sp. UENF 114111, Burkholderia silvatlantica UENF 117111 e Herbaspirillum seropedicae estirpe HRC 54), cinco concentrações de ureia (0, 2, 5, 7 e $\left.\log \mathrm{L}^{-1}\right)$ e em cinco épocas de avaliação do tempo de aclimatização (30, 60, 90, 120 e 150 dias após o plantio das mudas em bandejas), com quatro repetições. Verificou-se aumento na massa seca da parte aérea e massa seca da raiz de mudas micropropagadas de abacaxizeiro 'Vitória' em função da inoculação de bactérias diazotróficas. O tempo de aclimatização pode ser reduzida em até 60 dias em função da concentração de ureia.

Palavras-chave: Ananas comosus, bactéria promotora de crescimento vegetal, nitrogênio.

\section{INTRODUCTION}

The conventional methods of pineapple propagation result in low plantlets yields (MATOS et al., 2009) and high indices of disease contamination. Therefore, several alternative methods, such as removal of apical meristems (SANTOS et al., 2011), propagation from stem cuttings (FREITAS et al., 2012), and micropropagation (BALDOTTO et al., 2010), have been investigated in order to minimize these problems.

Pineapple micropropagation produces healthy and homogeneous plantlets that can be used for the establishment of stocks, especially for new cultivars (BALDOTTO et al., 2010; MATOS et al., 2009). However, plantlets produced from in vitro cultures have to switch from heterotrophy to autotrophy and possess abnormal anatomical and physiological characteristics, such as under developed leaf cuticle and lower stomatal density, which necessitates acclimatization in order for them to cope with edaphoclimatic conditions (BARBOZA et al., 2006). This requirement increases the price of micropropagated plantlets, and makes the price less

\footnotetext{
'Universidade Estadual do Norte Fluminense Darcy Ribeiro (UENF), 28013-602, Campos dos Goytacazes, RJ, Brasil. E-mail: aurilena.aviz@yahoo.com.br. "Corresponding author.
} 
competitive than that of plantlets produced using other techniques.

Some studies have been performed with the goal of improving the acclimatization of pineapple plantlets or testing the effects of different acclimatization times (BERILLI et al., 2011), foliar fertilization (BREGONCI et al., 2008), or inoculation with diazotrophic bacteria, which has been observed to positively affect the adaptation of pineapple plantlets to changes environments (BALDOTTO et al., 2010).

Nitrogen $(\mathrm{N})$ fertilization is one of the most important factors for pineapple development and results in increased seedling growth (FREITAS et al., 2012). However, $\mathrm{N}$ can also be supplied to plants via inoculation with diazotrophic bacteria. This strategy has become increasingly more common in agriculture (BALDOTTO et al., 2010) due to reductions in the use of $\mathrm{N}$ fertilizers, as observed in crops like soybeans (HUNGRIA et al., 2005) and sugarcane (BODDEY et al., 1995).

The interaction between mineral nutrition and diazotrophic bacteria may help minimize the critical effects during acclimatization, which is the final phase of pineapple micropropagation. In addition, the search for new technologies that are able to generate economical and ecological gains during seedling production is fundamental for Bioseedlings Tissue Culture Laboratory.

The aim of the present study was to evaluate the effect of $\mathrm{N}$ fertilization and inoculation with diazotrophic bacteria on the growth of micropropagated plantlets of the pineapple cv. 'Vitória' at different acclimatization times.

\section{MATERIAL AND METHODS}

The present study was conducted in a greenhouse situated on the campus of Universidade Estadual do Norte Fluminense Darcy Ribeiro (UENF) in Campos dos Goytacazes - RJ, Brazil (Latitude = $21^{\circ} 19^{\prime} 23^{\prime}$, Longitude $=41^{\circ} 10^{\prime} 40^{\prime \prime}$, Altitude $=14 \mathrm{~m}$ ). Average daily temperature $\left({ }^{\circ} \mathrm{C}\right)$ and average daily relative humidity $(\%)$ at the greenhouse were monitored and recorded using a KILOG data logger (KIMO Constructeur) during the experiment (Figure 1).

A randomized block experimental design with a $2 \times 5 \times 5$ factorial scheme was used, with the factors being two types of inoculum (absence or presence of a mix of diazotrophic bacteria, including Burkholderia sp. UENF 114111, Burkholderia silvatlantica UENF 117111, and Herbaspirillum seropedicae HRC 54), five urea concentrations $\left(0,2,5,7\right.$, and $\left.10 \mathrm{~g} \mathrm{~L}^{-1}\right)$, and five acclimatization times $(30,60,90,120$, and 150 days following the planting of plantlets in trays), and with four replicates of each treatment. Each replicate consisted of four plantlets grown in styrofoam trays. A total of 200 experimental units, corresponding to a total of 800 plantlets were evaluated.

Plantlets of the pineapple cv. 'Vitória' that were produced by in vitro propagation, with an average fresh weight of $0.30 \mathrm{~g}$, were obtained from the Bioseedlings Tissue Culture Laboratory (Laboratório de cultura de tecidos Biomudas). Urea fertilizer was applied to seedling leaves $(4 \mathrm{~mL}$ per experimental unit), at different times, in the following manner: $20 \%$ urea concentration on day $25,50 \%$ on day 50 , and $100 \%$ weekly from day 75 onward.

Bacterial strains were obtained from the bacteria collection of the Laboratory of Cellular and Tissue Biology (Laboratório de Biologia Celular and Tecidual) at UENF. Aliquots $(20 \mu \mathrm{L})$ of the bacterial stocks were diluted in liquid DYG'S culture medium (DÖBEREINER et al., 1995) and kept under constant agitation $\left(140 \mathrm{rpm}\right.$, at $30^{\circ} \mathrm{C}$ ) for 24 hours. The resulting pre-inocula were then used to produce larger volumes of inocula, under the same conditions. A final volume of $100 \mathrm{~mL}$ was obtained for each inoculum, with a density of $10^{8}$ cells per $\mathrm{mL}$.

The final inocula were dissolved in $5.7 \mathrm{~L}$ distilled water, and inoculation was performed by immersing the whole plantlets in the bacterial mix for 30 minutes. Control plantlets were immersed in distilled water. Plantlets were then transferred to trays containing Vivatto Slim Plus ${ }^{\circledR}$ commercial substrate and were sprayed with water, using a backpack sprayer, in order to prevent leaf dehydration. Fifteen days after the first inoculation, the substrate was inoculated with the same bacterial mix by applying $2 \mathrm{~mL}$ of the mix to each tray cell.

Fifteen days following seedling transfer, we began applying a complete nutrient solution (2mL per plant; RAMOS et al.(2009) to the leaves, weekly. From the third week onward, N was omitted from the nutrient solution. Complete nutrient solution was also applied to control plantlets on day 121 , in order to prevent seedling loss due to $\mathrm{N}$ deficiency. All fertilizations were performed after $17 \mathrm{~h}$, using a sterilized styrofoam chamber in order to prevent fertilizer drift and contamination between plantlets from different treatments.

At various time after seedling transfer $(30$, $60,90,120$, and 150 days), the following parameters were measured: seedling height, using a graduated ruler, grouping the leaves up, and measuring from the stem base to the tip of the largest leaf; number 


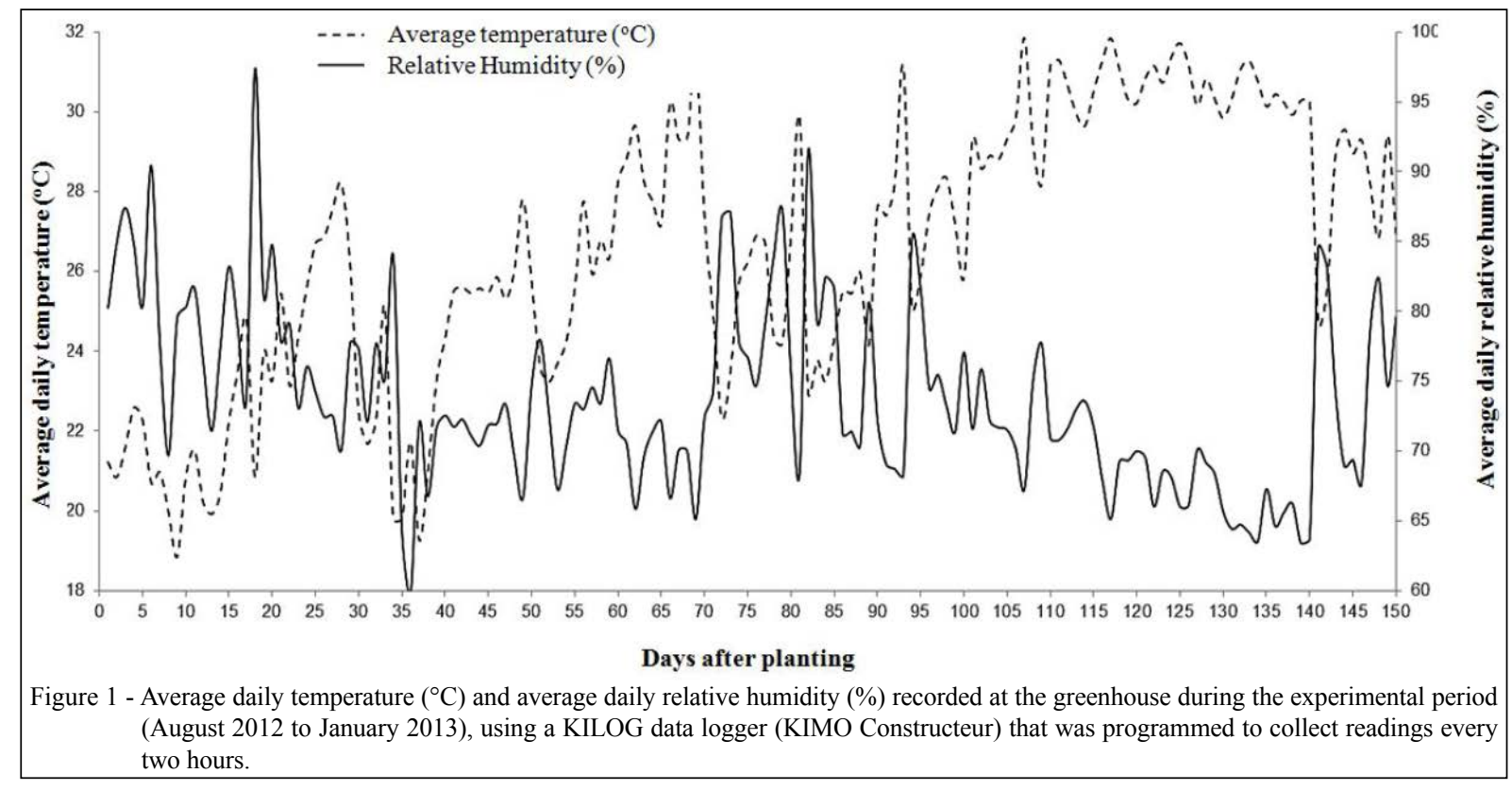

of leaves; leaf area, using a bench leaf area meter (model LI-3100, LICOR, Lincoln, NE, USA); shoot and root dry weight, following drying in a forced air ventilation oven, at $70^{\circ} \mathrm{C}$ until constant weight was reached. The number of bacteria in root samples was counted on days 30 and 150 , by performing serial dilutions from $10^{-3}$ to $10^{-7}$, and using semisolid JNFb medium (DÖBEREINER et al., 1995). The minimum number of cells per gram of root was considered for all treatments, based on the $10^{-1}$ dilution. Species were identified based on the color of the indicator, cell morphology, and colony morphology in plate cultures.

The minimum number of days and biometric characteristics needed to conclude acclimatization was estimated based on the knowledge that plantlets are considered to be ready for commercialization when they are 6 (BERILLI et al., 2011) to $12 \mathrm{~cm}$ high (in agreement with guidelines adopted by some Bioseedlings Tissue Culture Laboratory). The regression equations obtained for the relationship between urea concentrations and acclimatization time were used.

The data were subjected to a variance analysis (ANOVA). A polynomial regression analysis was performed for the quantitative variables (urea concentrations and acclimatization time). The best fit models, i.e., presenting a statistically significant analysis of variance and regression model with $\mathrm{F}$ test coefficient and highestR ${ }^{2}$, were selected. Qualitative variables (bacteria inoculation) were analyzed using a Tukey's test, at $\mathrm{P}<0.05$.

\section{RESULTS AND DISCUSSION}

No statistically significant three-way interaction was observed between the tested factors. However, the two-way interactions acclimatization time $\mathrm{x}$ urea concentration and acclimatization time $\mathrm{x}$ bacteria, in addition to the isolated effect of bacteria (i.e. inoculation), significantly affected the parameters that were quantified in plantlets of the pineapple cv. 'Vitória' (Tables 1, 2, 3, and Figure 2).

For the significant interaction between acclimatization time and bacteria inoculation that was observed for bacteria count, the bacterial population was $3 \log$ units higher in inoculated plantlets than in control plantlets at 30 days of acclimatization (Table 1). Then bacterial population have decreased at 150 days acclimatization, and the most probably number (MPN) of bacteria was not statistically significantly different between control and inoculated plantlets. These results are in accordance with REIS JUNIOR et al. (2004), who reported that diazotrophic bacteria populations might decrease over time.

Inoculation of pineapple plantlets with the diazotrophic bacteria mix also resulted in increases in shoot (SDW) and root dry weight (RDW) of $9.58 \%$ and $13.85 \%$, respectively (Table 2). Micropropagated plantlets with higher SDW and RDW are more 
Table 1 - Most probable number (MPN) of bacteria per gram root in the pineapple cv. 'Vitória' in response to inoculation with diazotrophic bacteria, at two different acclimatization times.

\begin{tabular}{|c|c|c|c|}
\hline \multirow{2}{*}{ Diazotrophic bacteria } & - & ------------- & \multirow{2}{*}{ Average } \\
\hline & 30 & 150 & \\
\hline \multicolumn{4}{|c|}{ } \\
\hline Absent & $3.91 \mathrm{~b} \mathrm{~A}$ & 2.72 a A & 3.31 \\
\hline Present & 6.96 a A & $2.84 \mathrm{a} \mathrm{B}$ & 4.90 \\
\hline Average & 5.43 & 2.78 & \\
\hline CV (\%) & ----------- & & \\
\hline
\end{tabular}

Averages that are followed by the same lower case letter within the same column or upper case letter within the same line were not significantly different according to the Tukey test, at $P<0.05$.

vigorous and may exhibit better adaptation in later phases, since the more developed the root system, the higher the nutrient uptake and plant growth. The observed RDW results are in accordance with BALDOTTO et al. (2010) and WEBER et al. (2003), who observed positive effects in micropropagated pineapple plantlets when inoculated with diazotrophic bacteria. However, it is important to note that while the effects of diazotrophic bacteria on plant growth and nutrition may be associated mainly with biological $\mathrm{N}$ fixation, other mechanisms may also be involved, such as the biosynthesis of indoleacetic acid (IAA) (BALDOTTO et al.,2010).

Regarding the interaction between acclimatization time and urea concentration, plantlets height increased more pronouncedly with increasing urea concentrations (Figure 2A). BERILLI et al. (2011) stated that plantlet height is an important biometric parameter for the acclimatization process, since it is used by several Bioseedlings Tissue Culture Laboratory to determine the end of the acclimatization phase. According to these authors, plantlets can be commercialized when they reach a height of 6 to $7 \mathrm{~cm}$, or 2 to $3 \mathrm{~g}$ shoot fresh weight. Other characteristics may also be used to determine the end of acclimatization. Specifically, higher leaf area may result in higher sunlight interception and dry weight, which may be used as reserve during post-planting adaptation.

Following 90, 120, and 150 days of acclimatization, plantlets fertilized with 10.0, 8.15, and $8.10 \mathrm{~g} \mathrm{~L}^{-1}$ urea produced estimated heights of $11.9,17.5$, and $20.4 \mathrm{~cm}$, respectively (Figure $2 \mathrm{~A}$ ). Decreasing N fertilization by approximately $20 \%$ relative to the highest concentration tested had no negative effects on plantlet height at 120 days following transplanting and, as such, represents a potential decrease in plantlet production costs (Figure 2A). This showed that fertilization management is fundamental during the plantlets acclimatization. It should be highlighted that,although fertilizer was applied to the leaves, some of the nutrient solution may have been taken up by the roots, as well.

The number of leaves (NL) increased linearly until 60 days of acclimatization. The highest estimated number of leaves per plantlets at 90, 120, and

Table 2 - Plant height (PH), number of leaves per plant (NL), leaf area per plant (LA), shoot dry weight (SDW), and root dry weight (RDW) of micropropagated plantlets of the pineapple cv. 'Vitória' that were either inoculated or not inoculated with diazotrophic bacteria. Average values of acclimatization time.

\begin{tabular}{lccccc}
\hline Diazotrophic bacteria inoculation & PH $(\mathrm{cm})$ & NL & LA $\left(\mathrm{cm}^{2}\right)$ & SDW (mg) & RDW (mg) \\
\hline No & $9.73 \mathrm{a}$ & $13.07 \mathrm{a}$ & $63.0 \mathrm{a}$ & $365 \mathrm{~b}$ & $39.7 \mathrm{~b}$ \\
Yes & $9.77 \mathrm{a}$ & $13.17 \mathrm{a}$ & $63.7 \mathrm{a}$ & $400 \mathrm{a}$ & $45.2 \mathrm{a}$ \\
Average & 9.75 & 13.12 & 63.3 & 382 & 42.5 \\
CV $(\%)$ & 8.27 & 7.08 & 18.18 & 30.6 \\
\hline
\end{tabular}

Averages that are followed by the same lower case letter within the same column are not significantly different according to the Tukey test, at $P<0.05$.

Ciência Rural, v.46, n.11, nov, 2016. 
Table 3 - Estimates of acclimatization time, number of leaves, leaf area, shoot dry weight, and root dry weight needed for micropropagated pineapple plantlets to reach an estimated height of between 6 and $12 \mathrm{~cm}$, when fertilized with different urea concentrations.

\begin{tabular}{|c|c|c|c|c|c|c|c|}
\hline \multirow{3}{*}{ Parameters } & \multirow{3}{*}{ Urea $\left(\mathrm{g} \mathrm{L}^{-1}\right)$} & \multirow{3}{*}{ Regression Equation } & \multirow{3}{*}{$\mathrm{R}^{2}$} & \multirow{2}{*}{\multicolumn{2}{|c|}{--------------X------------- }} & \multirow{2}{*}{\multicolumn{2}{|c|}{-----Plantlets height--- }} \\
\hline & & & & & & & \\
\hline & & & & $6 \mathrm{~cm}$ & $12 \mathrm{~cm}$ & $6 \mathrm{~cm}$ & $12 \mathrm{~cm}$ \\
\hline \multirow{5}{*}{ Acclimatization time (days) } & 0 & $y=0.0232 x+3.575$ & 0.84 & 104 & $363^{*}$ & - & - \\
\hline & 2 & $y=0.0813 x+1.336$ & 0.94 & 57 & 131 & - & - \\
\hline & 5 & $y=0.125 x-0.32$ & 0.95 & 51 & 99 & - & - \\
\hline & 7 & $y=0.1376 x-0.768$ & 0.95 & 49 & 93 & - & - \\
\hline & 10 & $y=0.1369 x-0.424$ & 0.95 & 47 & 90 & - & - \\
\hline \multirow{5}{*}{ Number of leaves } & 0 & $y=0.0125 x+8.777$ & 0.79 & - & - & 10 & - \\
\hline & 2 & $y=0.0577 x+7.72$ & 0.92 & - & - & 11 & 15 \\
\hline & 5 & $y=0.0784 x+6.857$ & 0.96 & - & - & 11 & 15 \\
\hline & 7 & $y=0.0832 x+6.603$ & 0.93 & - & - & 11 & 14 \\
\hline & 10 & $y=0.0859 x+7.048$ & 0.94 & - & - & 11 & 15 \\
\hline \multirow{5}{*}{ Leaf area $\left(\mathrm{cm}^{2}\right)$} & 0 & $y=0.1474 x+3.141$ & 0.95 & - & - & 19 & - \\
\hline & 2 & $y=0.0043 x^{2}+0.0278 x+1.668$ & 0.98 & - & - & 17 & 79 \\
\hline & 5 & $y=0.0114 x^{2}-0.5173 x+10.404$ & 0.99 & - & - & 14 & 71 \\
\hline & 7 & $y=0.01 x^{2}-0.1544 x-0.774$ & 0.98 & - & - & 16 & 71 \\
\hline & 10 & $y=0.0116 x^{2}-0.2698 x+2.47$ & 0.99 & - & - & 15 & 72 \\
\hline \multirow{5}{*}{ Shoot dry weight (mg) } & 0 & $y=1.0271 x+4.619$ & 0.94 & - & - & 111 & - \\
\hline & 2 & $y=0.0462 x^{2}-2.8242 x+93.118$ & 0.99 & - & - & 82 & 516 \\
\hline & 5 & $y=0.0935 x^{2}-6.9769 x+168.74$ & 0.99 & - & - & 56 & 394 \\
\hline & 7 & $y=0.0859 x^{2}-5.0473 x+110.99$ & 0.99 & - & - & 70 & 385 \\
\hline & 10 & $y=0.1103 x^{2}-8.2787 x+200.87$ & 0.99 & - & - & 55 & 349 \\
\hline \multirow{5}{*}{ Root dry weight (mg) } & 0 & $y=0.1294 x+19.419$ & 0.67 & - & - & 33 & - \\
\hline & 2 & $y=0.3928 x+8.766$ & 0.94 & - & - & 31 & 60 \\
\hline & 5 & $y=0.0043 x^{2}-0.2877 x+27.354$ & 0.95 & - & - & 24 & 41 \\
\hline & 7 & $y=0.0067 x^{2}-0.5942 x+35.14$ & 0.99 & - & - & 22 & 38 \\
\hline & 10 & $y=0.0051 x^{2}-0.3892 x+28.938$ & 0.99 & - & - & 22 & 35 \\
\hline
\end{tabular}

*According to the equation $\mathrm{y}=0.0232 \mathrm{x}+3.575,363$ days of acclimatization would be needed for pineapple plantlets to reach $12 \mathrm{~cm}$. However, this value is higher than the tested acclimatization period (150 days).

150 days of acclimatization was 16,18 , and 19 , with estimated urea concentrations of $9.2,7.5$, and $8.4 \mathrm{~g} \mathrm{~L}^{-1}$, respectively (Figure 2B). This is in agreement with COELHO et at. (2007), who observed a significant effect of $\mathrm{N}$ fertilization on the NL of plantlets receiving $10 \mathrm{~g} \mathrm{~L}^{-1}$ urea. Nitrogen deficient pineapples exhibit lower NL, with yellowish, small and narrow leaves (RAMOS et al., 2009). According to MOREIRA et al. (2006), micropropagated plantlets with higher NL may exhibit higher survival in the field and higher photosynthetic area for the production of organic matter.

The highest estimated leaf areas (LA) were 71,148 , and $216 \mathrm{~cm}^{2}$ per plantlets, observed at 90,120 , and 150 days of acclimatization, with estimated urea concentration of $11.5,9.0$, and $9.3 \mathrm{~g}$ $\mathrm{L}^{-1}$, respectively. Lower urea concentrations resulted in lower leaf area at these acclimatization times (Figure 2C). Decreasing $\mathrm{N}$ fertilization results in proportionately decreased leaf area, and it may be related to factors such as decreased cell pressure potential, increased cell wall rigidity, and/or decreased cell division (CRUZ et al., 2007).

At 120 and 150 days of acclimatization, the highest estimated SDW values were 643 and $1422 \mathrm{mg}$ per seedling, respectively, and were observed with estimated urea concentrations of 5.9 and $9.3 \mathrm{~g} \mathrm{~L}^{-1}$, respectively (Figure 2D). For the same acclimatization times, the highest estimated RDW values were 


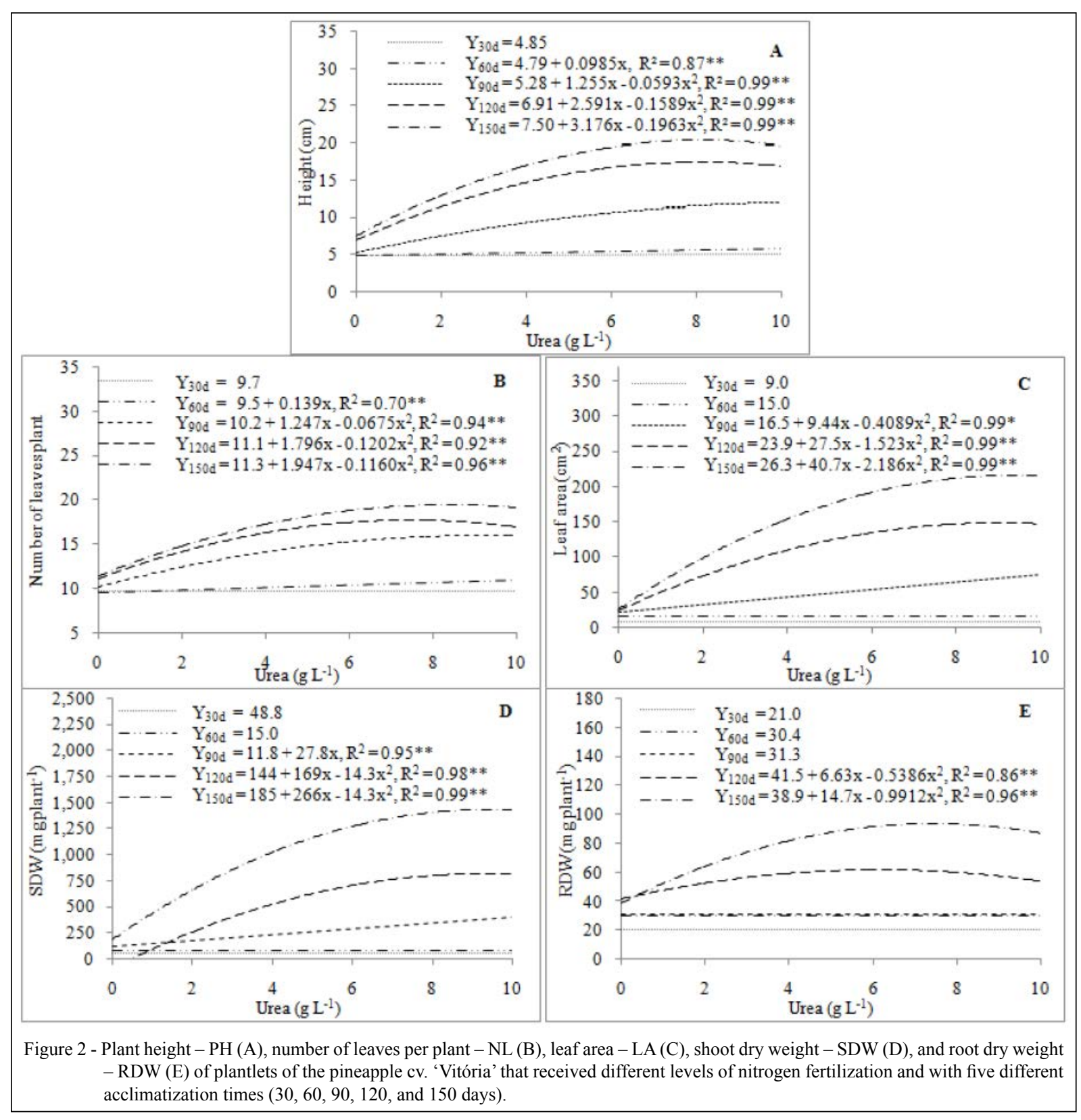

61.9 and $93.4 \mathrm{mg}$ per plantlets, with estimated urea concentrations 6.1 and $7.4 \mathrm{~g} \mathrm{~L}^{-1}$, respectively (Figure 2E). Although the highest SDW and RDW values were observed at 120 and 150 days, the minimum standard height of $6 \mathrm{~cm}$ demanded by Bioseedlings Tissue Culture Laboratory may be attained after only 90 days of acclimatization (Table 3). This means a decrease in the total time of plantlets production, since 150 days of acclimatization may be needed for the production of micropropagated pineapple plantlets. Indeed, $\mathrm{N}$ fertilization may result in a decrease of up to 57 days in the time necessary for plantlets to reach the minimum $6 \mathrm{~cm}$ height during acclimatization, when compared to plantlets that did not receive $\mathrm{N}$ fertilization. The maximum height of $12 \mathrm{~cm}$ was not achieved by non-fertilized plantlets and was attained up to 41 days earlier in plantlets receiving higher levels of $\mathrm{N}$ fertilization than in plantlets receiving only $2 \mathrm{~g} \mathrm{~L}^{-1}$ urea (Table 3).

Of the traits NL, LA, SDW, and RDW, none varied considerably between the three highest $\mathrm{N}$ concentrations tested, for the two minimum plantlets 
heights considered (Table 3). However, plantlets that were fertilized with $2 \mathrm{~g} \mathrm{~L}^{-1}$ urea exhibited higher values for these parameters at the end of acclimatization. The longer period of acclimatization likely allows the formation of leaves with more fibers, more voluminous stems, and larger roots, all of which result in increases in SDW and RDW measurements. However, a longer period of acclimatization would increase the plantlets production costs.

The results of the present study showed the potential for $\mathrm{N}$ fertilization to reduce the plantlets period. However, further studies are needed to verify plantlets behavior by following their transfer to the field.

\section{CONCLUSION}

Inoculation with bacteria promotes increased shoot and root dry weight of micropropagated plantlets of the pineapple cv. 'Vitória.' In addition, the management of $\mathrm{N}$ fertilization decreases the plantlets acclimatization time by approximately 60 days. Fertilization with urea at the higher concentrations tested, especially between 7.5 and $10 \mathrm{~g} \mathrm{~L}^{-1}$, also results in more precocious plantlets, and could be used by Bioseedlings Tissue Culture Laboratory as a strategy to decrease the plantlets time.

\section{REFERENCES}

BALDOTTO, L.E.B. et al. Selection of growth-promoting bacteria for pineapple 'Vitória' during acclimatization. Revista de Brasileira de Ciência do Solo, v.34, p.349-360, 2010. Available from: <http://www.scielo.br/pdf/rbcs/v34n2/v34n2a08.pdf $>$. Accessed: Jan. 2012. doi: 10.1590/S0100-06832010000200008.

BERILLI, S.S. et al. Evaluation of the development of different sizes of micropropagated seeedlings of pineapple tree, after acclimatization. Revista Brasileira de Fruticultura, v.33, p.208-214, 2011. Available from: <http://www.scielo.br/pdf/rbf/ v33n1/aop00311.pdf>. Accessed: Feb. 2012. doi: 10.1590/S010029452011005000018.

BODDEY, R.M. Biological nitrogen fixation in sugar cane: akey to energetically viable biofuel production. Critical Reviews in Plant Sciences, v.14, p.263-279, 1995. Available from: <http:// www.tandfonline.com/doi/pdf/10.1080/07352689509701929>. Accessed: Jan. 2014. doi: 10.1080/07352689509701929.

BREGONCI, I.S. et al. Foliar fertilization with macro and micronutrients in the growth of plantlets micropropagated of pineapple cv. 'Gold' [Ananas comosus (L.) Merrill] in different containers. Ciência e Agrotecnologia, v.32, p.705-711, 2008. Available from: $<$ http://www.scielo.br/pdf/cagro/v32n3/a01v32n3.pdf $>$. Accessed: Nov. 2012. doi: 10.1590/S1413-70542008000300001.
COELHO, R.I. et al. Response to fertilization with urea, potassium chloride and boric acid in the 'Smooth Cayenne' pineapple plants. Revista Brasileira de Fruticultura, v.29, p.161-165, 2007. Available from: <http://www.scielo.br/pdf/rbf/v29n1/ a33v29n1.pdf>. Accessed: Nov. 2012. doi: 10.1590/S010029452007000100033.

CRUZ, J.L. et al. Nitrogen levels and photosynthetic rate of papaya 'Golden'. Ciência Rural, v.37, p.64-71, 2007. Available from: $<$ http//www.scielo.br./pdf/cr/v37n1/a11v37n1.pdf $>$. Accessed: Feb. 2014. doi: 10.1590/S0103-84782007000100011.

DÖBEREINER, J. et al. Como isolar e identificar bactérias diazotróficas de plantas não-leguminosas. Brasília: EmbrapaSPI /Embrapa-CNPAB, 1995. 60p.

FREITAS, S.J. et al. Brassinosteroid and nitrogen fertilization on growth and nutritional status of seedlings from pineapple sectioning stem. Revista Brasileira de Fruticultura, v.34, p.612-618, 2012. Available from: <http://www.scielo.br/pdf/rbf/v34n2/37.pdf $>$. Accessed: Jan. 2013. doi: 10.1590/S0100-29452012000200037.

HUNGRIA, M. et al. The importance of nitrogen fixation to soybean cropping in South America. In: WERNER, D.;NEWTON, W.E. (Ed.). Nitrogen fixation in agriculture, forestry, ecology, and the environment. Dordrecht: Springer, 2005. p.25-42.

MATOS, A.P. et al. Produção de mudas sadias de abacaxi. Cruz das Almas: Embrapa Mandioca e Fruticultura Tropical, 2009. 12p.

MOREIRA, M.A. et al. Acclimatization of micropropagated pineapple plants cv. 'Pérola': substrata effect. Ciência e Agrotecnologia, v.30, p.875-879, 2006. Available from: <http:// www.scielo.br/pdf/cagro/v30n5/v30n5a08.pdf $>$. Accessed: Dec. 2011. doi: 10.1590/S1413-70542006000500008.

RAMOS, M.J.M. et al. Visual symptons of macronutrients and boron deficiency in 'Imperial' pineapple. Revista Brasileira de Fruticultura, v.31, p.252-256, 2009. Available from: $<$ http://www. scielo.br/pdf/rbf/v31n1/v31n1a35.pdf >. Accessed: Nov. 2011. doi: 10.1590/S0100-29452009000100035.

REIS JUNIOR, F.B. et al. Identification of Azospirillum amazonense isolates associated to Brachiaria spp. at different stages and growth conditions, and bacterial plant hormone production. Revista Brasileira de Ciência do Solo, v.28, p.103113. 2004. Available from: <http://www.scielo.br/pdf/rbcs/v28n1/ a11v28n1.pdf>. Accessed: Feb. 2014. doi: 10.1590/S010006832004000100011 .

SANTOS, P.C dos. et al. Mycorrhizal fungi on growth and nutrition of sprouts from pineapple crown. Revista Brasileira de Fruticultura, v.33, p.658-665, 2011. Available from: <http:// www.scielo.br/pdf/rbf/v33nspe1/a92v33nspe1.pdf $>$. Accessed: Jun. 2013. doi: 10.1590/S0100-29452011000500092.

WEBER, O.B. et al. Effect of diazotrophic bacteria on pineapple Cayenne Champac plantlets with different substrates. Pesquisa Agropecuária Brasileira, v.38, p.689-696, 2003. Available from: $<$ http://www.scielo.br/pdf/pab/v38n6/18217.pdf $>$. Accessed: Jan. 2012. doi: 10.1590/S0100-204X2003000600004. 